\title{
Agricultural expansion during the post-civil war period in southern Angola based on bi-temporal Landsat data
}

\author{
Anne Schneibel, Marion Stellmes, Rasmus Revermann, Manfred Finckh, Achim Röder \\ \& Joachim Hill
}

\begin{abstract}
The repopulation of abandoned areas in Angola after the 27 years of civil war led to a fast and extensive expansion of agricultural fields to meet the rising food demand. This effect is supported by the improvement of infrastructure and has a large impact on the natural vegetation.We evaluated agricultural expansion in our study area in the south of Angola by using Landsat data with a resolution of $30 \times 30 \mathrm{~m}$ per pixel, combined with RapidEye data ( 5 × $5 \mathrm{~m}$ per pixel) and high resolution imagery (Bing Maps, 0.41 x $0.41 \mathrm{~m}$ and Google Earth, $1.5 \times 1.5 \mathrm{~m}$ ). We applied a bi-temporal change detection approach on a spectral difference Landsat image, based on four images for 1997/1998 and 2008/2009 each. After calculating an unsupervised classification (ISODATA), change classes were manually assigned based on spectral information from Landsat data and visual information of the higher resolution data. In order to analyse which land cover type was most affected by the agricultural practices, we additionally carried out an unsupervised classification approach in combination with knowledge-based assignment of classes for 1997/1998. We furthermore estimated the relationship between infrastructure and the establishment of new fields by manually capturing roads and tracks based on high resolution imagery (Bing Maps \& Google Earth) and recent RapidEye data.The results indicate that together with the repopulation of the study area, the area of fields strongly increased, which had a considerable impact on natural vegetation. Furthermore, the high impact of the presence and quality of infrastructure on the location and the spatial expansion of fields could be proved. We found that more than 47,000 ha (equals $2.85 \%$ of the total study area) of new fields were established during the 11 years and mainly open woodlands, shrublands and dense woodlands were cleared for slash and burn agriculture. Furthermore, more than $93 \%$ of these active agricultural areas are located within less than $5 \mathrm{~km}$ distance to the roads and $46 \%$ even lie within a 1-km distance to the present infrastructure.
\end{abstract}

Keywords: Change analysis; deforestation; ISODAT; Landsat 5 TM; land use classification; Okavango; slash-and-burn

Expansão agrícola durante o período pós-guerra civil no sul de Angola com base em dados bitemporais Landsat

Resumo: O repovoamento de áreas abandonadas em Angola, após os 27 anos de guerra civil, resultou em rápida e extensa expansão de campos agrícolas para atender a crescente demanda por alimento. Este efeito é consequência da melhoria das infraestruturas e causa grande impacto na vegetação natural. Avaliamos a expansão agrícola em nossa área de estudo no sul da Angola utilizando dados Landsat com resolução de $30 \times 30 \mathrm{~m}$ por pixel, conjugados com dados RapidEye, 5 x 5m por pixel, e imagens de alta resolução (Bing Maps, 0,41 x 0,41m, e Google Earth, 1,5 x 1,5m). Aplicamos uma abordagem de detecção de alterações bitemporal em uma imagem Landsat de diferença espectral, com base em quatro imagens para os biênios1997/1998 e 2008/2009. Após calcular uma classificação não-supervisionada (ISODATA), alterações de classes foram atribuídas manualmente de acordo com a informação espectral de dados Landsat e a informação visual dos dados de maior resolução. A fim de analisar qual tipo de cobertura do solo foi mais afetado pelas práticas agrícolas, realizamos, também, uma abordagem de classificação não-supervisionada em combinação com atribuição baseada no conhecimento de classes para 1997/1998. Calculamos ainda a relação entre a infraestrutura e a criação de novos campos, capturando manualmente estradas e caminhos com base em imagens de alta resolução (Bing Maps e Google Earth) e dados RapidEye recentes. Os resultados indicam que, junto com o repovoamento da área de estudo, as áreas de campo tiveram um crescimento significativo, causando impacto considerável na vegetação natural. Foram comprovados, ainda, o grande impacto no local causado pela presença e qualidade da infraestrutura, e a expansão espacial dos campos. Verificamos que mais de 47 mil hectares (equivalente a $2,85 \%$ do total da área estudada) dos novos campos foram ocupados durante os 11 anos, sobretudo florestas abertas, matagais e bosques que foram derrubados para a agricultura à base de desmatamento e queimada, além de que, $93 \%$ dessas áreas agrícolas ativas, estão localizadas a menos de $5 \mathrm{~km}$ de distância das estradas e $46 \%$ até mesmo a $1 \mathrm{~km}$ de distância da infraestrutura atual.

Palavras-chave: Análise de mudança; classificação do uso do solo; corte-e-queima; desmatamento; ISODATA; Landsat 5 TM; Okavango.

Received: 11 September 2013 - Accepted: 23 November 2013

\section{Introduction}

The civil war in Angola, which intermittently lasted for 27 years until 2002, had a high impact on population dynamics. It led to rural depopulation and the expansion of urban areas, where people were seeking for safety and basic supplies. In particular the abandonment of agricultural areas caused a shortage in food supplies during these years (Kibble 2006). In the post-civil war period, population increased from 13.9 million in 2000 to 19.9 million in 2010 , which equals a rise of $43 \%$ (FAO 2012). This is also due to the return of a high number of former refugees from neighbouring countries. Although agricultural production increased as well, e.g. cereal production by more than $100 \%$ in one decade (1999-2009), Angola still strongly 


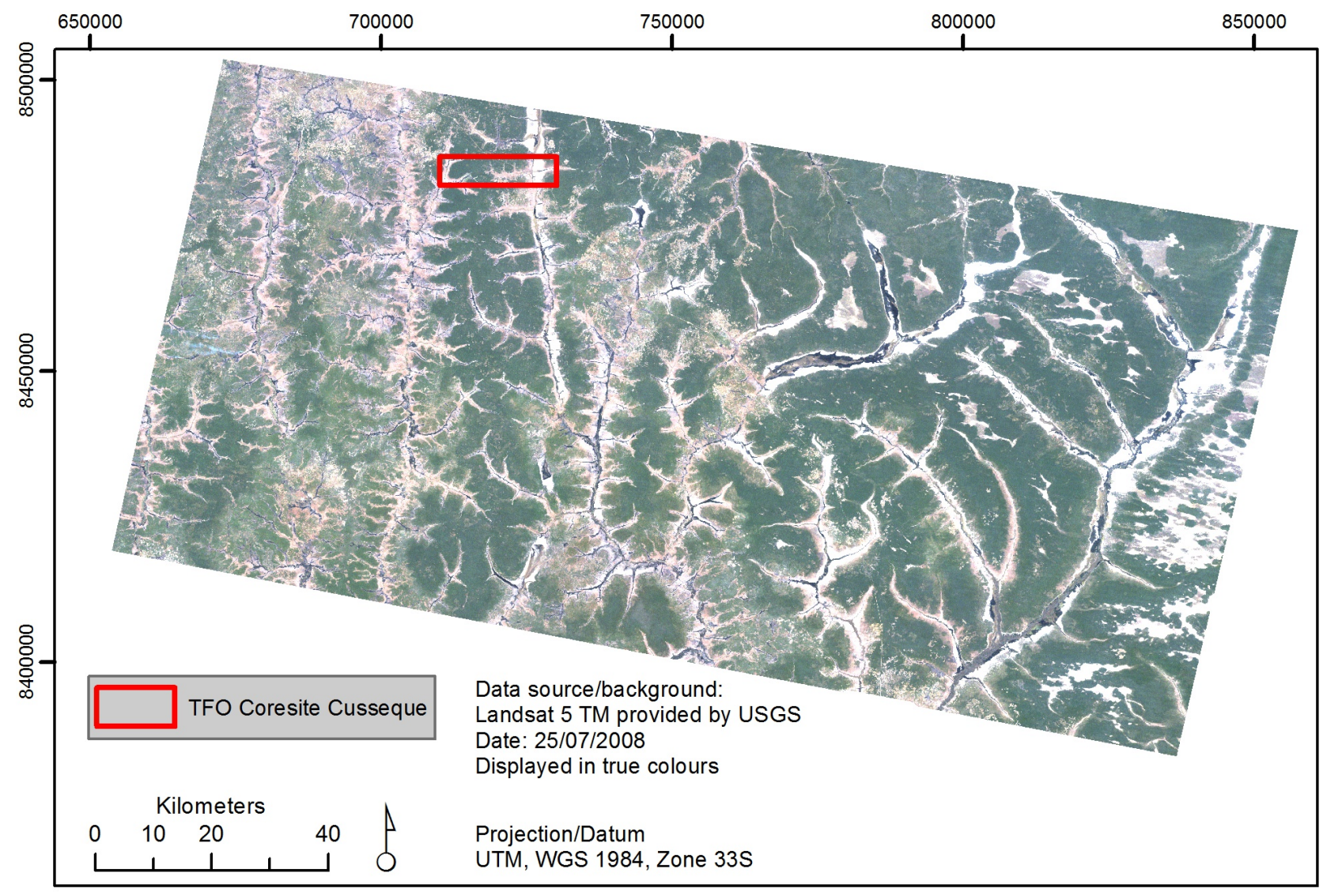

Fig. 1: Study area according to the Landsat $5 \mathrm{TM}$ frame. The Cusseque core-site from the TFO project is displayed in red.

depends on food imports. Cereal imports for example more than doubled in 2009, which clearly shows that there is a need of increasing agricultural production (http://faostat.fao.org). Currently, most of the rural population is dependent on subsistence farming and practices slash and burn agriculture. Thus, an increase in production equals a higher rate of clearing woodlands for cultivation. However, this has to be seen in the context of the practices inherent to shifting cultivation. Due to nutrient poor soils, fields are generally only used for a period of 3-5 years (Gröngröft et al. 2013) and new areas have to be cleared to replace the old ones. The development of new fields heavily relies on a functioning infrastructure, providing direct access to the fields on the one hand and on the other hand enabling access to markets to sell the products. Hence, next to investments in advancing local agriculture, infrastructural improvements will also be a key in increasing the production. The FAO currently ranks the quality of infrastructure in Angola at an index-value of 1.7 , where 0 would be lowest and 5 the highest possible score (FAO 2012). Food supply, amount of trade and agricultural development (e.g. by fertilizers or equipment) strongly depend on infrastructural expansion and improvement.

We expect that the area of agricultural fields in our study area strongly increased since the truce until the present day. As mentioned above, expansion and improvement in agriculture are furthermore supposed to coincide with an increase in number and quality of roads/tracks (Kibble 2006). The pattern of potential and actual deforestation along the streets has also been observed in other studies, e.g. in the Mato Grosso state in southern Brazil (Morton et al. 2006) or in

two states of south and south-eastern Mexico (Deininger \& Minten 2002). Geist and Lambin (2002) indicate that infrastructural expansion is one of the main drivers for deforestation (also including slash and burn agriculture) in tropical forests. We therefore also expect that most of the newly established fields are in close distance to roads and that mainly woodlands are affected by clearing of natural vegetation.

The detection of land use and land cover change requires spatially explicit multi-temporal data ( $\mathrm{Lu}$ et al. 2004). The incorporation of the Landsat Archive allows us a retrospective analysis of land

Table 1: Corresponding Landsat scenes acquired for the change analysis. All scenes were available from the Landsat 5 Thematic Mapper.

\begin{tabular}{ccc}
\hline 1997/1998 & 2008/2009 & Season \\
\hline 11 July 1997 & 25 July 2008 & Dry season \\
28 August 1997 & 11 September 2008 & End of dry season \\
09 April 1998 & 22 March 2009 & End of wet season \\
25 May 1998 & 25 May 2009 & Start of dry season \\
\hline
\end{tabular}



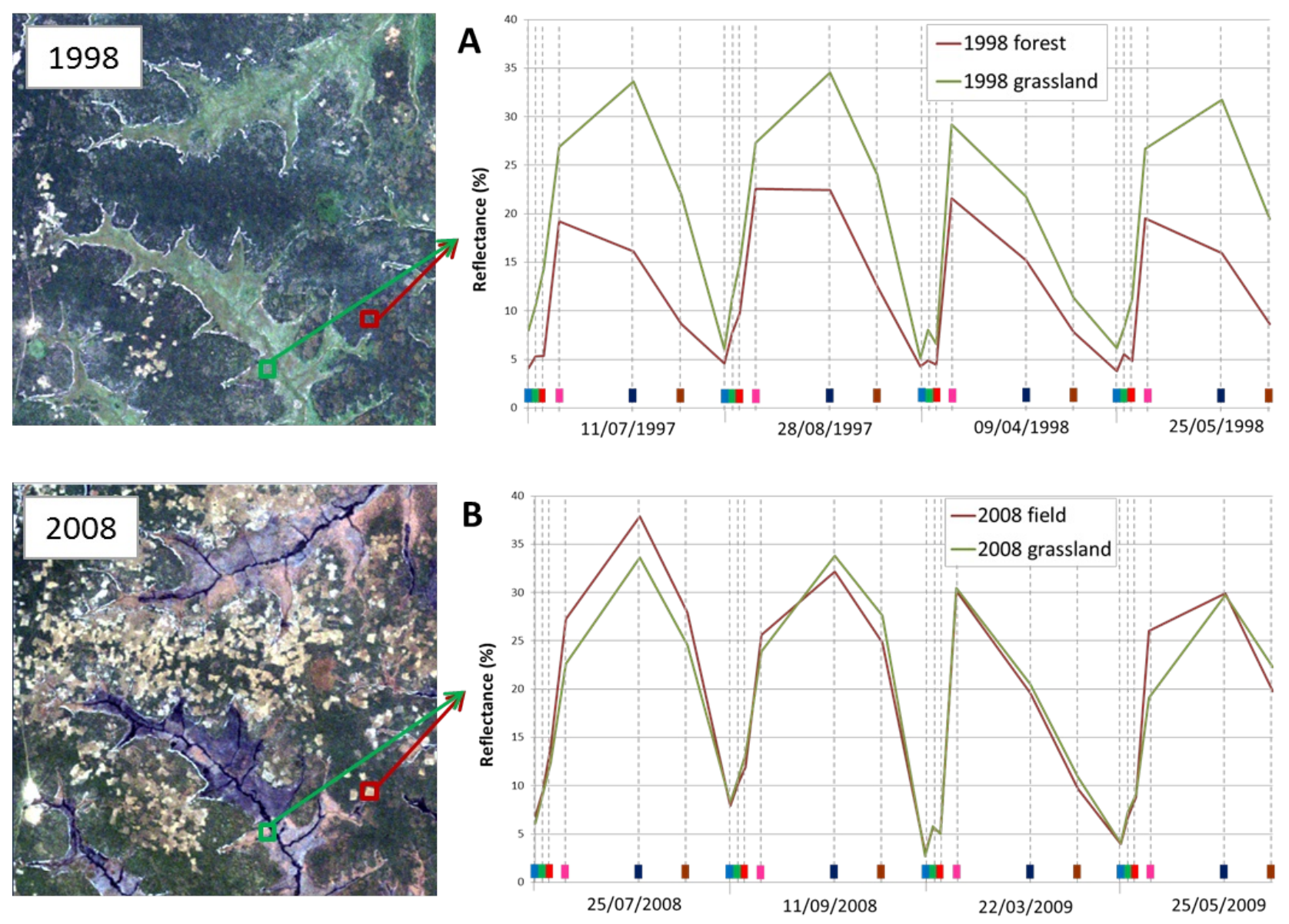

Landsat band: blue $(0.485 \mu \mathrm{m})$, green $(0.560 \mu \mathrm{m}), \mathbf{r e d}(0.660 \mu \mathrm{m})$, [near infrared $(0.830 \mu \mathrm{m})$, short wave infrared $(1.650 \mu \mathrm{m})$,

short wave infrared $(2.215 \mu \mathrm{m})$

Fig. 2: Landsat 5 TM spectra collected in 1997/1998 and 2008/2009. The green spectrum represents grassland. The red spectrum shows a woodland type in 1997/1998, which is converted into an agricultural field until 2008/2009. The bands and their corresponding wavelengths are given as coloured boxes. Field and grassland show similar spectral characteristics throughout the year (2008/2009), which impedes the separation. By incorporating an earlier time step (1998), the conversion of natural vegetation into an agricultural field can be detected.

use changes. Several change detection approaches exist and have to be implemented corresponding to the thematic issue and the existing preconditions. Our approach falls into the area of land conversion detection by applying a bi-temporal approach, i.e. comparing images for two dates (Coppin et al. 2004). An overview over further techniques and requirements can be found in $\mathrm{Lu}$ et al. (2004) and Coppin et al. (2004).

Summarized, our research questions are:

- Can the area under cultivation, which was established between 1997/1998 and 2008/2009 be quantified?

- What is the impact of the location of roads to the establishment of new agricultural fields?

- Are there different influences of earth and tarred roads on agricultural dynamics?

- Which type of land cover/ vegetation units is mainly cleared for agriculture?

\section{Study Area}

Our study area is situated in the central highland of Angola in the southern part of the Bié province and the northern part of the Cuando Cubango province. It is located in the upper Okavango catchment where open to dense Miombo woodlands occur dominated by trees of the genera Brachystegia, Cryptosepalum and Julbernardia. Slopes leading down to the river valleys are covered by dwarf shrub/grasslands whereas the valley bottoms feature open floodplains and wetlands with thick peat layers dominated by
Cyperaceae and reeds (see factsheet on vegetation in the Cusseque core site in this issue).

The study area shows a gradient of highly populated areas in the western part, compared to mostly natural areas in the eastern part. This is also reflected in the degree of fragmentation of the woodlands. In the western part, woodlands are cleared for agriculture use and rural expansion and hence are highly fragmented, while in the eastern part the woodlands remain mainly untouched (Fig. 1).

The local population generally relies on subsistence farming (Kibble 2006) and parts of the woodlands are traditionally used for slash and burn agriculture. Large agricultural projects are currently absent in the entire region. For people in rural and remote areas, slash and burn can be considered as a relatively sustainable land 


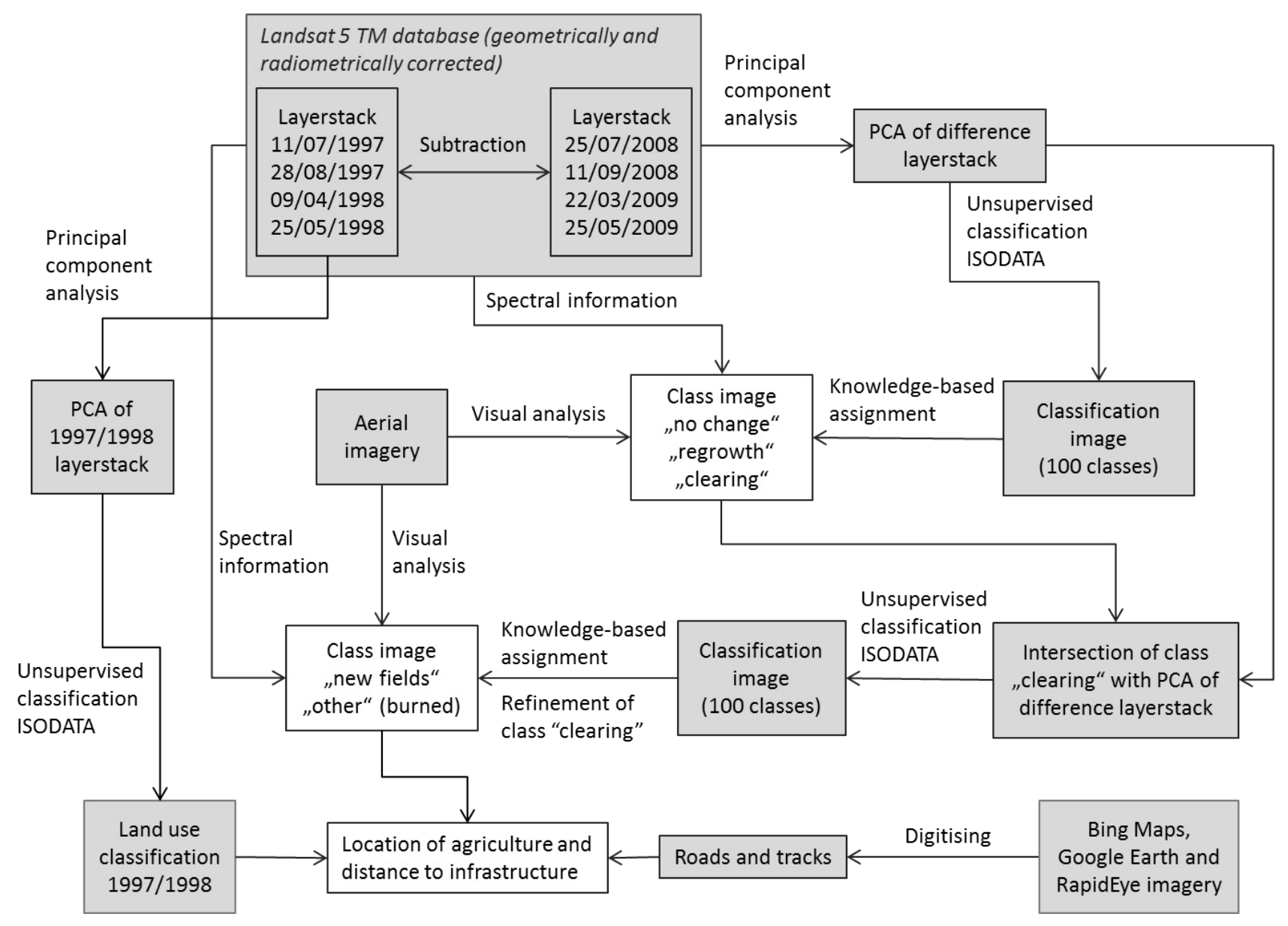

Fig. 3: Workflow of the classification scheme, including information on infrastructure. The grey boxes indicate input data and intermediate steps. The white boxes illustrate the two class images and the spatial analysis result.

use system as long as population density is low (Inoue et al. 2009). Although the cleared woodlands provide space for agriculture and hence food for the people, important ecosystem services such as provisioning of timber for construction, firewood or wild fruits will decrease in return.

\section{Materials}

For our study, data with different spatial and temporal resolution is required. The classification and change detection approach is mainly based on multiseasonal Landsat data from two time steps. The Landsat scenes were provided by the United States Geological Service (USGS, acquired via Earth Explorer). The study area is covered by the Landsat images path 179 and row 70 in the corresponding Worldwide Reference System (WRS).

Additionally, very high resolution imagery was available from BingMaps
(0.41 x $0.41 \mathrm{~m}$, DigitalGlobe/ GeoEye 2013) provided by the Microsoft Corporation and its data suppliers. For clouded areas, Google Earth images with a resolution of $1.5 \times 1.5 \mathrm{~m}(\mathrm{CNES} / \mathrm{Spot}$ Image 2013) were provided by Google Inc. 2013. For areas, where Google Earth and Bing Map imagery were clouded, Rapideye data (5 x $5 \mathrm{~m}$ resolution) was available by an image grant from the RapidEye Science Archive (RESA) for May 2013.

\section{Landsat dataset}

For the detection of newly established fields, Landsat $5 \mathrm{TM}$ data were used, since the Landsat sensor provides an acceptably dense database since 1984 . The Landsat 5 TM sensor acquires data in three visible wavelength ranges, so-called "bands", which are blue $(0.485 \mu \mathrm{m})$, green $(0.56 \mu \mathrm{m})$ and red $(0.66 \mu \mathrm{m})$. Furthermore, one band in the near infrared $(0.83 \mu \mathrm{m})$ and two bands in the short-wave infrared $(1.65 \mu \mathrm{m}$ and 2.215 $\mu \mathrm{m}$, respectively) are available.

According to data availability, we used four dates from different phenological stages, at the end of the rainy season, one at the start of the dry season, one during the dry season and one at the end of the dry season. We selected scenes from the years 1997/1998 and more recently from $2008 / 2009$. In order to allow for direct comparisons between the two time steps, images need to be from the same phenological stage. This leads to the data base displayed in Table 1.

\section{Data pre-processing}

Prior to the analysis, the Landsat images need to be geometrically and radiometrically corrected. Geometric correction is essential to locate points of interest, to match adjacent images, to provide a correct overlap of images from different sensors and dates and to incorporate images into geographic databases (Kardoulas et al. 1996). Radiometric correction is particularly 
necessary in multi-temporal analysis because these approaches rely on consistent temporal reflectance trajectories. Atmospheric conditions are likely to contribute to spectral response variability and hence, real changes in the signal have to be separated from the noise (Schroeder et al. 2006).

\section{Geometric correction}

The Landsat data is provided geometrically corrected by USGS. Our study area is located in the northern part of the original Landsat frame (Fig. 1). The images were subsetted to the extent of the study area and to the extent for which all data overlap. The essential precondition of high geometric accuracy between the datasets was visually examined.

\section{Radiometric and topographic correction}

Atmospheric and illumination effects have to be removed to reconstruct the original target signal, which was reflected by the earth's surface. We applied radiometric correction by using the AtCPro software (Hill et al. 1995) which accounts for atmospheric absorption, scattering and topographic effects. AtCPro is principally based on a modified 5S-Code, which was originally presented by Tanré et al. (1990). The parameterization of this approach is done by incorporating contemporaneous MODIS (MOD09) acquisitions. For a detailed description see Hill et al. (2011) and Hill et al. (2014, in press)

\section{Methods}

\section{Field expansion}

We applied a multi-seasonal, bi-temporal approach to enable a reliable separation of newly established fields from other land cover types. The bi-temporal approach is necessary, since certain land cover classes are spectrally highly similar for some periods during the year. This is especially the case for active fields and sparse grass-/shrublands, which is due to the rainfed agriculture practiced in the study area (Fig. 2B).

The time profiles for 2008/2009 show that the spectra of the grassland and the field have the same characteristics for the selected dates (Fig. 2B). The incorporation of the land cover type, which was present before the establishment of the field makes a separation of converted areas feasible. This is comprehensible when regarding the spectra presented for 1997/1998 (Fig. $2 \mathrm{~A})$. The present agricultural area (2008/2009) was covered by a woodland type in $1997 / 1998$, which in return shows different spectral characteristics to the grassland area. Hence, a combination from an early and a recent date can clearly enable separation possibilities of changed from unchanged areas.

For the selected approach, the images from 1997/1998 were stacked according to the time when they were recorded, i.e. from July 1997 to May 1998 and from July 2008 to May 2009. In this way, one single file per time step was produced, each consisting of 24 bands. For the change detection analysis we subtracted the bands from the corresponding dates, i.e. band 1 of the July image 2008 was subtracted from band 1 of the July image 1997 and so forth. This results in one single image with 24 difference layers.

We applied a principal component analysis (PCA) on this difference image

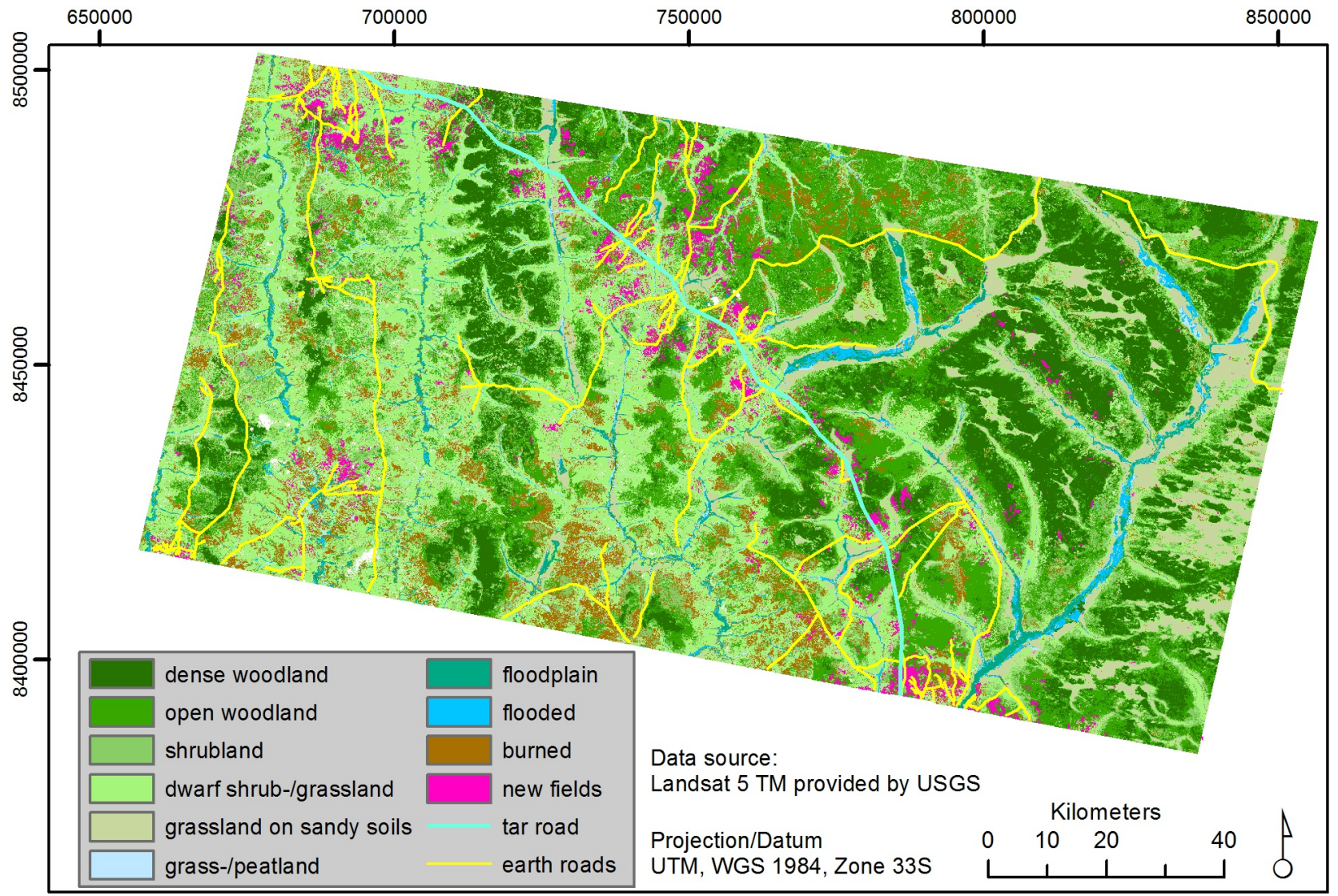

Fig. 4: Land use classification for 1997/1998. The new fields and roads are overlaid to depict, which type of land cover is preferably cleared for the establishment of new fields. 


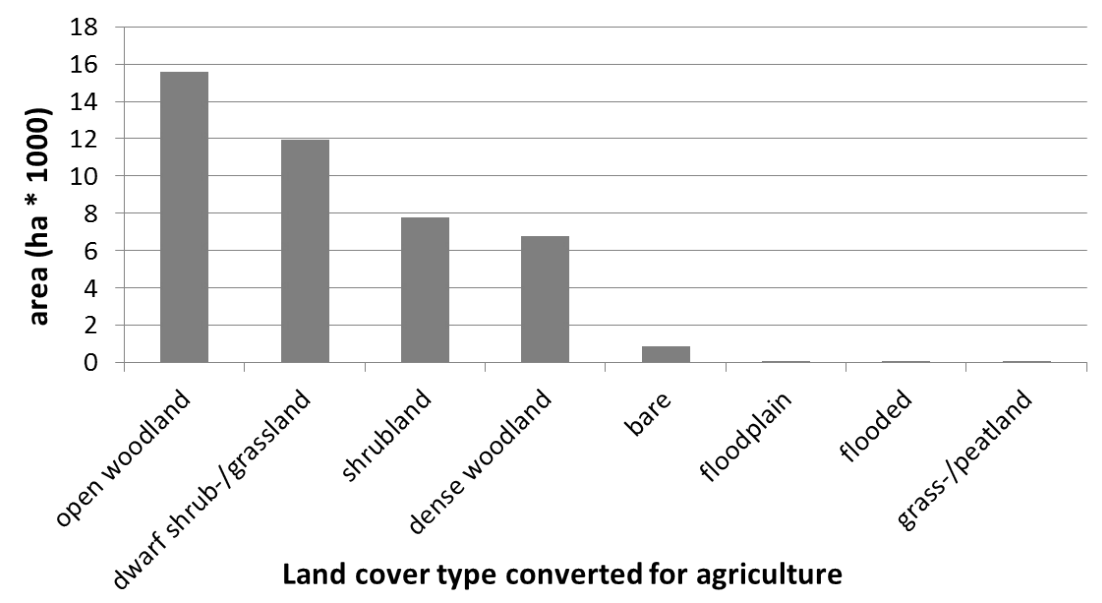

Fig. 5: Type of land cover, which was cleared to establish new fields between 1998 and 2009.

to decorrelate the axes in the multispectral and -temporal data space and to rotate the data according to their accounting variance. Subsequently, the PC-rotated bands were z-standardized to adjust the influence of each band in the unsupervised classification approach ("Iterative self-organizing data analysis technique": ISODATA), which is applied

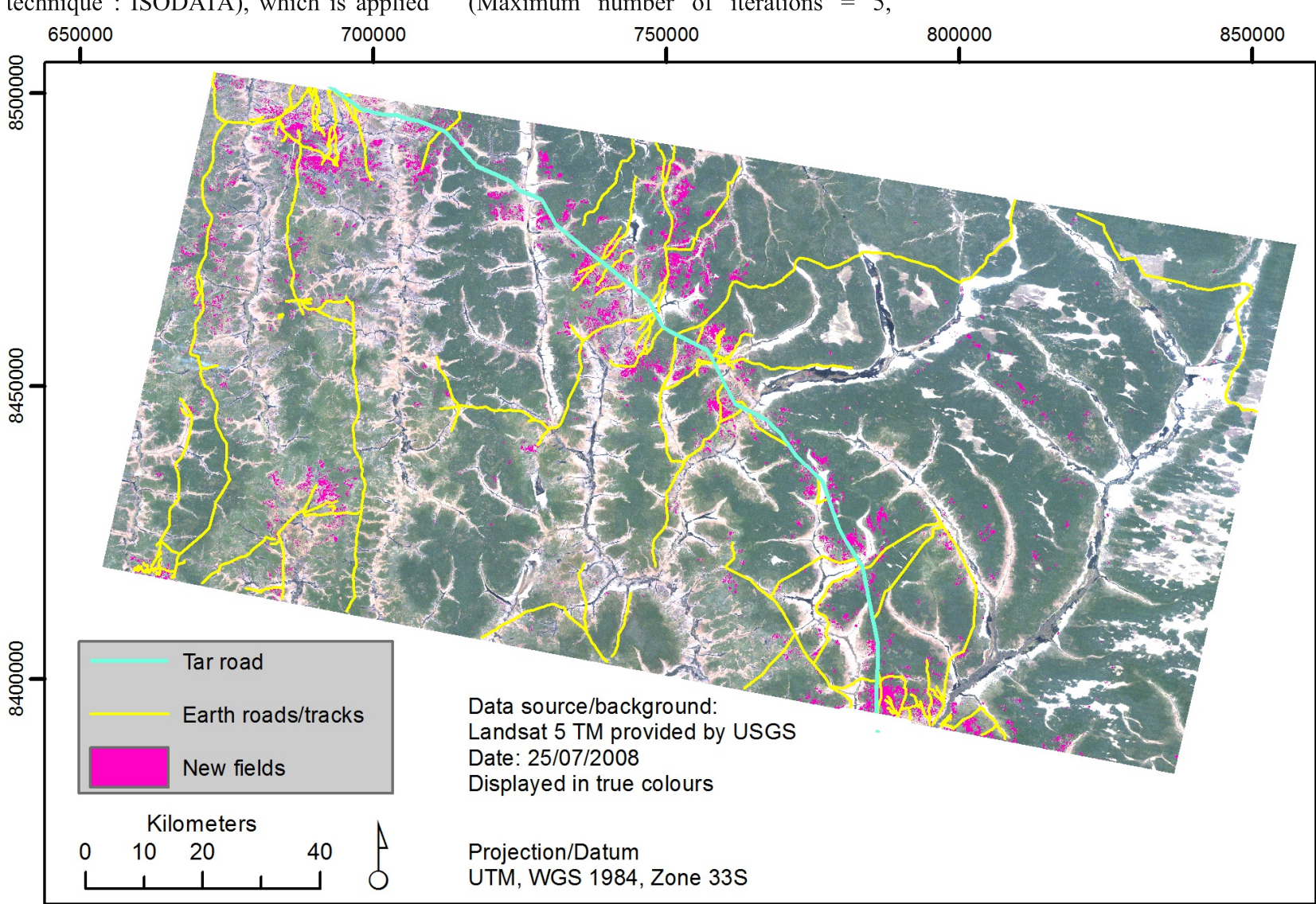

Fig. 6: Result from the detection of field expansion and the manual capturing of roads. Active fields, which were established between 1998 and 2009, are shown in pink, present earth roads in yellow and the main tar road in cyan. change threshold $=1 \%$, minimum number of pixels per class $=1$, maximum standard deviation $=1$, minimum class distance $=5$ ). The approach returned the maximum of 100 classes, which were labelled manually. For this purpose, high resolution imagery provided by Bing Maps, the two layer-stacks of Landsat scenes and their spectral response were visually analysed to identify agricultural areas, which were established after $1997 / 1998$ and before 2008/2009. First of all, we distinguished between three categorical classes: (i) no change, (ii) clearing and (iii) regrowth, respectively.

At this step of the analysis, the class "clearing" does not only consist of expanded agriculture, but can also be caused recently by uncontrolled fires. To explicitly detect the areas, where new fields were established, we applied the ISODATA algorithm again on those areas, which were labelled as "clearing" during the first run. We used the same parameterization and 100 classes were again provided by the ISODATA algorithm. They were subsequently categorised by the same procedure mentioned above. This led to the to vary between a minimum of 50 up to a maximum of 100 classes, depending on the defined statistical thresholds (Maximum number of iterations $=5$, principle of maximizing the variance between and minimizing the variance within the groups (Tou \& Gonzalez 1981). The number of classes was defined 800000 


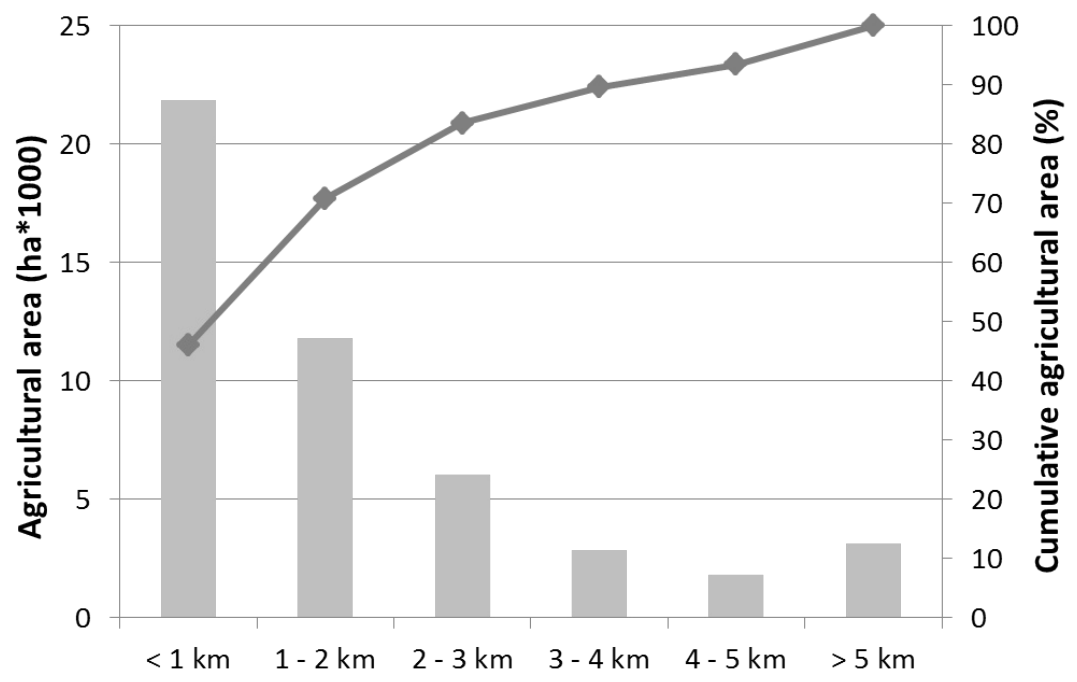

distance to road

Fig. 7: Area of fields, established after 1998, corresponding to their distance to roads/track. The bar chart presents the proportion on the total area according to the distance to the infrastructure. The curve shows the cumulative area of active fields.

identification of areas covered by natural vegetation in 1997/1998 and which were in agricultural use in 2008/2009.

\section{Land cover classification for 1997/1998}

To define which type of land cover was mainly cleared to establish new fields, a land cover classification is calculated for 1997/1998. This is done by a similar approach as for the change detection, i.e. by an unsupervised ISODATA classification that was applied on the 1997/1998 PC-rotated, standardized layer-stack. The classes were manually labelled to: woodland, open woodland, shrubland, dwarf shrub- and grassland, grass-/peatland, grassland on sandy soil, floodplain and flooded. This had to be based on the spectral information provided by the Landsat data, since no high resolution data was available for this time. Furthermore, the results were cross checked with data on vegetation plots, which were investigated within the TFO project. We intersected this classification with the areas that we labelled as active fields in 2008/2009 to receive information on the proportions of the respective land cover types, which were cleared for the expansion of agriculture.

\section{Infrastructural Influences}

To connect the information of agricultural expansion to the development of road

infrastructure, tar roads and earth roads were identified and manually captured. The digitising of these roads and tracks requires data of higher spatial resolution, as linear elements are hard to detect on Landsat resolution

If possible, we used high resolution imagery, provided by Bing Maps (Bing Maps Aerial). For a small region, where no Bing Maps were available or where clouds occurred, Google Earth imagery was assessed. In the case that neither Bing Maps nor Google Earth provided adequate imagery, RapidEye data was used instead. We defined those structures as earth roads/tracks which were on the one hand possible to be captured by the available resolution and on the other hand larger than a trail.

To evaluate the distances of the fields to the roads and which road type mainly enhances agricultural expansion, we applied five buffers along all roads, with intervals of $1 \mathrm{~km}$. Fields occurring in the tar road buffer as well as in the earth road buffer were assigned to the tar road. In this way, double counting is avoided and it can be assumed that earth roads in this area are mainly established due the present tar road to which they are connected. The workflow of the implemented change detection scheme in connection with infrastructure and information on land cover types is illustrated in Figure 3.

\section{Results \& discussion}

\section{Field expansion}

The total area of the fields which were established between 1997/1998 and $2008 / 2009$ and which are still in use today extents to 47,600 hectares. This area equals $2.85 \%$ of the total study area. Fields, which were established after 1998 but are fallows today, were not captured by our approach. The class regrowth, which has been defined in the first ISODATA cycle, mainly consisted of areas, which were burned in 1997/1998 and not affected by fires in 2008/2009.

Separation from fallows requires further information, either temporal, e.g. by using a time-series, or spatially, e.g. by implementing approaches that consider shape parameters.

\section{Land cover classification for 1997/1998}

We also evaluated the land use types, which were cleared for agricultural expansion. The result of the land use classification shows that in the western part, dense woodlands are mainly situated on the elevated areas following the topography and in the eastern part cover a large extent of the study area, where only few roads and settlements exist (Fig. 4). These woodlands are characterised by the evergreen tree Cryptosepalum exfoliatum ssp. pseudotaxus. They are generally less affected by shifting cultivation. One reason could be that they are located further away from potential access routes, e.g. in the eastern part of the study area. Another reason could be that they occur on nutrient poor soils thus making them less attractive for cultivation as observed in the Cusseque core site (personal observation). However, detailed data to clarify this point are not yet available.

In our study area, agriculture was mainly developed in the western part, in open woodlands, grass-/shrublands and dense woodlands (Fig. 5). Since we did not use a time series, we have to assume that those areas, where grassland was cleared for agriculture, might also be reactivated fallows. This could also explain the large area of dwarf shrub- and grassland (12,000 hectares), which was converted to agriculture.

Other land cover types like bare, floodplain, flooded areas or grass/peatlands are not influenced by agricultural expansion, which is coherent 
as they do not offer adequate conditions for cropping. However, peatlands are used for horticulture, but only on a very small scale, which is not detectable by the Landsat spatial resolution (see factsheets on the Cusseque core site in this issue).

\section{Infrastructural Influences}

Figure 6 gives an indication that agricultural areas were mainly implemented adjacent to settlements or roads. We did not capture settlements, since their structure is only visible in very high resolution imagery. In Google Earth imagery and RapidEye data, settlements are not clearly detectable as they are spectrally highly similar to bare ground or very sparse grasslands. In our study area, several settlements are located along the main road showing a structure of radial agricultural growth around them. In contrast, the agricultural areas also expanded parallel to the main road (Fig. 6). The two towns Chitembo and Menongue are located in the northeast and southwest of the study area, where a strong increase in agriculture is visible. However, only the outskirts of these urban areas are included as the full extent does not form part of the Landsat data frame.

Almost half of the new fields were established closer than $1 \mathrm{~km}$ to existing roads $(46 \%)$. More than $70 \%$ lie within a $2 \mathrm{~km}$ radius and more than $90 \%$ are within a $5 \mathrm{~km}$ distance (Fig. 7). These findings indicate that the establishment of new fields is especially located in short walking distance to roads and tracks.

Regarding the different road types, the only tar road, which crosses the study area, has a length of about $159 \mathrm{~km}$. This is less than one tenth compared to the network of earth roads, which extends to a total length of , $1652 \mathrm{~km}$. In total, most of the fields are located along the earth roads $(28,050 \mathrm{ha})$ compared to the tar road $(16,327$ ha). Nevertheless, comparing the agricultural area in relation to the road length, fields are more likely to be established along the tar road (102.8 $\mathrm{ha} / \mathrm{km}$ ) compared to the earth road (17 $\mathrm{ha} / \mathrm{km})$. This can on the one hand be explained by better access to the agricultural areas and on the other hand with the connection of fields to larger settlements, which are mainly located along the tar road. Although settlements also occur along wider earth roads, which are visible in the south western part of our study area, people rather tend to settle along the main roads due to a faster and better infrastructural connection.

\section{Conclusion and outlook}

The present study shows that multiseasonal Landsat $5 \mathrm{TM}$ data from two time steps and ten years apart in combination with higher spatial resolution data are appropriate to detect the dynamics of agricultural expansion in a study area in southern Angola. The extensive growth of agriculture in this area is closely connected to an increase in population density, also caused by the repopulation of formerly abandoned areas. The presented approach was developed to answer four research questions linked to the spatial pattern of expanding agriculture and its relation to infrastructure.

The first research question was aiming at the quantification of the agricultural area that was established in the study area within ten years, between 1997/1998 and $2008 / 2009$. Our approach proved to be successful in identifying these areas of new agricultural fields. Nevertheless, further studies including more time steps and segmentation approaches might provide more detailed insight on the spatial and temporal dynamics of agricultural land use.

Concerning the impact of the local and spatial distribution of roads and their influences on location of new fields, we clearly detected an interrelation. This supports the assumption that people tend to establish new fields in short distance to infrastructure. In further studies, field information on the location of settlements could improve understanding of the dynamics and structure of new agriculture. Concerning the type of street, we found an explicit difference between the influences of earth and tarred roads on agricultural dynamics. This is also connected to settlement dynamics, since people tend to take up residence along the main road. Hence, we can state that the improvement of infrastructure will strongly influence the spatial expansion of fields. With a denser time series, agricultural dynamics could be additionally linked to infrastructure as well as population increase.

We could furthermore define the major land use types that were cleared for agriculture, although some issues remain, especially regarding the crop rotation. This result could be enhanced, either by incorporating further temporal information or if available, by using data with higher spatial resolution. The separation between natural dwarf shruband grasslands and on the other hand grass dominated fallows was not possible with the presented approach but will probably be detectable with a dense time series. Of importance for sustainable land management is information on the duration of cultivation of fields and the fallow periods which could be used to estimate the turnover of cultivated land and the necessary area to sustain the population. Furthermore, the impact of a growing population and the increased demand for agricultural area on natural ecosystems can be forecasted.

\section{Acknowledgements}

The study was carried out in the framework of the project "TFO - The future Okavango", which is funded by the Federal Ministry of Education and Research (BMBF). This support is gratefully acknowledged. The authors would also like to thank the United States Geological Survey (USGS), the National Aeronautics and Space Administration (NASA), the Microsoft Corporation and its data suppliers, Google Inc. and the RapidEye Archive Database (RESA) for providing the imagery including important pre-processing and products, which were essential for this study. The authors wish to thank two reviewers for providing helpful comments and suggestions that greatly helped to improve the manuscript.

\section{References}

Bing Maps Aerial - ( 2012 DigitalGlobe $\odot$ 2012 GeoEye State of Michigan

Chander, G., Markham, B. L., Helder, D.L. (2009): Summary of current radiometric calibration coefficients for Landsat MSS, TM, ETM+, and EO-1 ALI sensors. Remote Sensing of Environment 113: 893-903. CrossRef

Coppin, P., Jonckheere, I., Nackaerts, K., Muys, B., Lambin, E. (2004): Digital change detection methods in ecosystem monitoring: a review. - International Journal of Remote Sensing 25: 1565-1596. CrossRef

Deininger, K., Minten, B. (2002): Determinants of Deforestation and the Economics of Protection: an Application to Mexico. - American Journal of Agricultural Economy 84: 943-960. CrossRef

FAO (2012): FAO Statistical Yearbook 2012: Africa Food and Agriculture. 
FAOSTAT: Food and Agriculture Organization Corporate Statistical Database. - - URL: http://faostat.fao.org/site/609/default.asp X\#ancor [accessed on: 2013-08-12]

Geist, H.J., Lambin, E.F. (2002): Proximate Causes and Underlying Driving Forces of Tropical Deforestation. - Bioscience 52: 143-150. CrossRef

Hay, J.E., McKay, D.C. (1985): Estimating solar irradiance on inclined surfaces: a review and assessment of methodologies. - International Journal of Solar Energy 3: 203-240. CrossRef

Hill, J., Mehl, W., Radeloff, V. (1995): Improved forest mapping by combining corrections of atmospheric and topographic effects. - In: Askne J. [Ed]: Sensors and environmental application of remote sensing. Proceedings of the 14th EARSeL symposium, Göteborg, Sweden, 6-8 June 1994 (p. 143-151). Rotterdam, Brookfield: A. A. Balkeman

Hill, J., Stellmes M., Stoffels J., Werner W., Frantz D., Stern O. (2011): Assessing the sensitivity of the European beech (Fagus sylvatica L.) to drought stress based on remote measurements from earth observation satellite. - In, 1st Forestry Workshop: Operational Remote Sensing in Forest Management. 2-3 June 2011, Prague, Czech Republic

Hill J., Stellmes M., Changyao W. (2014, in press): Land transformation processes in NE China: Tracking trade-offs in ecosystem services across several decades with Landsat-TM/ETM+ time series. - In: Manakos I. \& Braun M. [Eds]: Land Use and Land Cover Mapping in Europe. Remote Sensing and Digital Image Processing; \#99. Springer New York, Berlin

Inoue, Y., Qi J., Kiyono, Y., Ochiai, Y., Horie, T., Shiraiwa, T., Asai, H., Saito, K., Dounagsavanh, L., Olioso., A. (2009): Land use and carbon stock capacity in slash-and-burn ecosystems in mountainous mainland of Laos. - In: Röder, A., Hill., J. [Eds.]: Recent Advances in Remote Sensing and Geoinformation Processing for Land Degradation Assessment. London: Taylor \& Francis Group

Kardoulas, N.G., Bird, A.C., Lawan, A.I. (1996): Geometric Correction of SPOT and Landsat Imagery: A Comparison of Map- and GPS-Derived Control Points. - Photogrammetric Engineering \& Remote Sensing 62: 1173-1177.

Kibble, S. (2006): Can the Politics of Disorder Become the Politics of Democratisation \& Development? Review of African Political Economy 33: 525-542. CrossRef

Lu, D., Mausel, P., Brondízio, E., Moran, E. (2004): Change detection techniques. International Journal of Remote Sensing 25: 2365-2407. CrossRef

Morton, D.C., DeFries, R.S., Shimabukuro, Y. E., Anderson, L. O., Arai, E., del Bon
Espirito-Santo, F., Fraitas, R., Morisette J. (2006): Cropland expansion changes deforestation dynamics in the southern Brazilian Amazon. - Proceedings of the National Academy of Sciences of the United States of America 103 14637-14641. CrossRef

Schroeder, T.A., Cohen, W.B., Son, C., Canty, M.J., Yang, Z. (2006): Radiometric correction of multi-temporal Landsat data for characterization of early successional forest patterns in western Oregon. - Remote Sensing of Environment 103: 16-26. CrossRef

Tanré, D., Deroo, C., Duhaut, P., Herman, M., Morcrette, J.J., Perbos, J., Deschamps, P.Y. (1990): „Technical note description of a computer code to simulate the satellite signal in the solar spectrum: the $5 S$ code". - International Journal of Remote Sensing 11 : 659-668. CrossRef

Groengroeft, A. Luther-Mosebach, J., Landschreiber, L., Eschenbach, A. (2013): Cusseque - Soils. - Biodiversity \& Ecology 5: 55-57. CrossRef

Tou, J.T, Gonzalez, R.C. (1981): „Pattern Recognition Principles". - AddisonWesley Publishing Comp., Reading, Massachusetts

\section{Affiliations}

Anne Schneibel* (schneibel.anne@unitrier.de), Marion Stellmes (stellmes@unitrier.de), Achim Röder (roeder@unitrier.de), Joachim Hill (hillj@uni-trier.de) Department of Environmental Remote Sensing and Geoinformatics, Faculty of Regional and Environmental Sciences

University of Trier

Behringstr. 21

54286 Trier, GERMANY

Rasmus Revermann

(rasmus.revermann@botanik.uni-

hamburg.de), Manfred Finckh

(manfred.finckh@uni-hamburg.de)

Biodiversity, Evolution and Ecology of

Plants, Biocentre Klein Flottbek and

Botanical Garden

University of Hamburg

Ohnhorststr. 18

22609 Hamburg, GERMANY

*Corresponding author 
